\title{
Institutional Quality in Fostering Financial Development in Emerging Market Economies
}

\author{
Henok Neguse Negash ${ }^{*} \quad$ Hu Hongbing \\ School of Finance, Zhongnan University of Economics and Law, \#182 Nanhu Avenue, East Lake High-tech \\ Development Zone, Wuhan, 430073, China \\ * E-mail of the corresponding author: henura33@gmail.com
}

\begin{abstract}
This research explores the role and importance of institutional quality in promoting financial development in emerging market countries. The panel dataset was conducted on 26 emerging countries for the period covering 1999-2019. The dataset was collected from major sources including World Governance Indicators (WGI) from World Bank, International Financial Statistics office (IFS), and World Development Indicators (WDI). We used GMM and 2SLS methods to analyze the behavior of the components of institutional quality including political stability, regulatory quality, rule of law, control over corruption, government effectiveness, and voice and accountability in influencing financial development. According to the results obtained, well-functioning institutions have the capability to promote financial development. Countries that have improved their institutional quality and governance systems have scored high rates of financial development. A unit increase in the components of institutional quality has a positive and significant influence on financial development. This indicates that poor institutions lead to poor financial growth.
\end{abstract}

Keywords: Institutional Quality, Emerging Market Economies, Financial Development, Institutions, Regulatory Framework.

DOI: $10.7176 / \mathrm{RJFA} / 12-10-01$

Publication date:May $31^{\text {st }} 2021$

\section{Introduction}

The idea whether institutional quality can cause real effect on the process of financial development has been greatly navigated in recent years. The strength of the institutional and governance frameworks can potentially determine the path of financial development and growth. It is of no doubt that the importance of well-functioning financial sector is crucial for having a healthy economic progress and stability. To this end, the financial institutions and markets - as main pillars of financial development - play vital role in the growth of financial development of any economy. Well-functioning banks and capital markets have the potential to contribute to a more efficient allocation of resources, capital, innovation, and other dynamic efficiency gains over time. The strength and ability of the financial system to impact the economic growth mainly depends on the formation of good quality institutions. Over the past decades, tremendous market and institutional reforms have been taken both in developing and developed economies so as to foster their economic growth. However, the progress and stability level of financial development in developing and emerging economies is significantly lower compared to the progress and stability of those developed economies.

The unparalleled need for financial progress and development of all levels of economies has tremendously increased in the past three decades. Many countries have been engaged in establishing a well-found financial system to support their economic growth. Most of them however, have been circling in the bank-based system that has been proved not as efficient as the market-based economic system. After the great global financial crisis of $2007 / 2008$, the first priority of policy makers in different economies has been and still is the strengthening of the financial sector and making it too big to fail in times of financial turmoil. There is a large literature which has been established focusing on the significance of financial sector development for the overall growth and equity of economies. It is strongly believed that regardless of how big an economy might be, if it has fragile financial system, it is possible that this economy can create major financial crises. Thorsten Beck and Asli Demirguc-kunt, May 2009, introduced the updated and extended version of the Financial Development and Database Structure and presented the structure and development of financial markets and institutions across countries. They added indicators on banking structure and financial globalization in their research methodology. They found that a deepening of both financial markets and institutions, a trend concentrated in high-income countries and more pronounced for markets than it is for banks.

A vast body of literature estimated the impact of financial development on economic growth, inequality, and stability. A typical empirical study proxy financial development with either one of two measures financial depth - the ratio of private credit to GDP or stock market capitalization to GDP. However, these indicators do not take into account the complex multidimensional nature of financial development. To correct this omission, the Financial Development Index was developed for the IMF staff discussion note "Rethinking Financial Deepening: Stability and Growth in Emerging Markets." It summarizes how developed financial institutions and financial markets are 
in terms of their depth (size and liquidity), access (ability of individuals and companies to access financial services), and efficiency (ability of institutions to provide financial services at low cost and with sustainable revenues and the level of activity of capital markets).

One of the major variables that affects the performance of these institutions (Financial markets and institutions) as the main pillars of financial development is the institutional quality. Institutional quality is defined as the factor that include socio-economic, culture, religion, corruption, political stability, government efficiency, voice of accountability and transparency, and internal and external conflicts and resolutions. Although most of its determinants are non-financial variables they have greater impact in the short and long term of the financial development and economic progress. For most of the developing and emerging economies, these factors have been among the major challenges that hinder the desired progress and stability. Therefore, this research is intended to investigate and show the role of having high or low institutional quality on financial development. Governance is a concept that plays a vital role in the overall economic and financial development of countries. On one hand, financial development as a multi-faceted factor has greater influence to promote and foster economic growth. On the other hand, the factors that affect the growth and progress of financial development are inevitably significant and with a great degree of impact to the output. There are numerous micro and macroeconomic factors and nonfinancial factors that affect the two main pillars of financial development (Financial markets and Financial institutions) of any economy.

\section{Literature Review}

The analysis with regard to the role of financial system in the growth process has been continuously improved by the development of theoretical models of endogenous growth integrating the financial sphere since the work of Schumpeter (1912) and Gurley and Shaw (1955). Schumpeter's work (1912) underlined that the financial system determines who gets the opportunity to use public savings which in turn has a great effect in resource allocation, enhancing the expected productivity, and attaining the long-term economic growth. It was clearly stated that the accumulation of capital and technological innovation are not the sole factors that differentiate the progress and level of financial and economic development among countries. In a more recent literatures regarding growth underscored the role of financial development and institutional quality as major and fundamental drivers of economic growth. This depicts that macroeconomic stability and progress and financial liberalization are not sufficient to explain the whole equation of financial deepening of financial factors which eventually leads to the necessity of having good quality institutions. Growth will undoubtedly high in the context where institutions are operating efficiently and it will be weak in the environment where institutions are performing inefficiently. Reforms and revisions of institutional environment and governance is capable of stimulating growth in most of merging and developing countries.

Douglass North (1990) has defined institutions as set of rules and standards of a society or, more formally, the constraints established by men who frame and regulate behaviors. His work described institutions as formal and informal institutions. According North's (1990) description, the formal institutions are said to include laws, rules, and constitutions whereas the informal institutions incorporate conventions, self-imposed codes of conduct, and unwritten social behavior standards. Following the definition of institutions by North (1990), it was clearly distinguished that the economic institutions would certainly govern and structure the rules of the economic game and concern including execution of contracts, property rights, and assuring transparency while the political institutions adhere to political stability, bureaucracy, and democracy, Daron Acemoglu et al. (2004). Therefore, according to the works of North and later Daron, the economic and political institutions were the ones to be abided by the rule of law to the extent that there exists proper functioning of the sectors of production and exchange. Nelson and Sampat (2001) magnified the need for the conception of institutions is to establish a certain order and thereby reducing the potential risks and uncertainties from the process of financial and economic process.

Many theories have been emerged that try to explain the relationship between financial development and economic growth and stability by taking into account the economic and financial factors. The theories usually have undermined or isolated the importance of the non-economic and non-financial influential factors that have the potential to determine the pace of financial and economic growth. Therefore, it is imperative to look at those variables and integrate them with the financial and economic systems. Ross Levine (2001) described and empirically examined that the law and finance theory stresses that legal traditions differ in terms of their emphasis on the rights of private property owners vis-à-vis the state and their ability to adapt to changing commercial and financial conditions, so that historically determined legal traditions shape financial development today. Levine (2001) underlined that other theories reject the centrality of legal tradition in accounting for cross-country differences in financial development. The results are broadly consistent with legal theories of financial development, though it is difficult to identify the precise channel through which legal tradition influences financial development.

The importance of financial development in fostering and attaining a sustainable economic growth has been the subject of academic and empirical focus of discussion over the last three decades. The fore pillars of financial 
development being financial markets and financial institutions, economic and financial drivers play an important role in assuring those institutions operate in the desired level of efficiency and effectiveness so that the output matches the expectations. However, it is necessary to emphasis that a good quality institutions are major determinants in assuring stable financial development in time.

Levine (1998), Levine et al. (2000), King and Levine (1993), have explained in their studies the positive link between the level of financial development and economic growth and stability. A recent study by Hiroyuki Ito and Masahiro Kawai (2018) has shown the quantity and quality measure of financial development and found that quality and quantity measures of financial development are highly correlated with each other for advanced economies and Asian emerging economies. The study has proved that the quality measure of financial development has a positive effect on output growth and negative effect on output volatility and inflation for emerging economies with relatively high-quality of financial development. In their study the disaggregated components of the quality measures suggest that it is the level of legal and institutional development that differentiates advanced economies from emerging and developing economies in terms of the quality measures. This indicates that a profound legal system and institutional quality is a prerequisite to standardized quality of financial development. When countries experience certain degree of financial sector progress, it is the reflection of having well-defined institutional quality and legal system that encourages institutions to run smoothly.

The very fact that it is imperative to study the role of institutional quality on financial development is due to the ongoing growing significance of financial development in promoting and fostering economic growth and stability. There is of course two school of thoughts toward if financial development promotes economic growth or economic growth fosters financial development. Robinson (1952) and Lucas (1998), stated that financial development plays a limited role in fostering economic growth. They asserted that when the economy develops, the financial system also develops. Robinson (1952) underscored that "where enterprises go, finance follows". Lucas (1998) asserted that economists "badly-over-stress" the role of financial factors in economic growth. Rajan and Zingales (1998) or Cameron (1967), argued that financial development is only a lubricant for economic growth and stability but nor the major component. According to their argument, it is the availability of profitable investment opportunities that are highly essential to foster economic growth and progress. The second school of thought goes quite the opposite direction of what has been mentioned above. The school highly advocates the significance of financial development in the process of growth, innovation, and economic development, (Bagehot, 1873, Schumpeter, 1911, MacKinnon 1973, Levine 1997). Their thoughts emphasis that causality proceeds from financial to economic development; it is only at a later stage that financial development leads on to growth. Haber, North and Weingast, (2008) assert that "countries do not have large banking systems and securities markets because they are wealthy; they are wealthy because they have large banking systems and securities markets". Similarly, for King and Levine (1993), finance does not merely follow in the wake of economic activity. They affirm that the significant robust relationship between the degree of financial development and the rate of economic growth indicates much more than a positive association between contemporaneous shocks and financial/economic development. For Levine (1997), there is even evidence according to which the level of financial development is a good predictor of future rates of growth, capital accumulation and technological change. Gerschenkorn (1962) argued that a developed financial system is a key condition for industrialization and that over the long sweep of history, the contribution of financial markets to economic growth has been significantly important (Stiglitz, 2010), pivotal (Schumpeter, 1912), or even too obvious for serious discussion (Miller, 1998).

The main focus is then how does the concept of financial development gives the right expected output in the long-run to support the economic growth. As mentioned in the introductory part of this research, there are few researches made toward what the role of other variables are in fostering and moderating financial development specifically in emerging and developing economies. Anwar and Cooray (2012) understated that South Asian countries have benefited to their financial development due to frequent improvements in their political rights and civil liberties which in turn has a positive effect in their economic growth. Many assumptions evolve around the concept of the constituent variables of financial development that significantly triggers its stable growth and progress. Financial development is subject to an aggregate effects in the economy. It is influenced by economic and non-economic factors. Institutional quality, trade openness, inflation, financial openness, income, money supply, interest rates, exchange rates, investments, and fiscal policies have direct or indirect influence on the outcome and level of financial development.

More recent works that include scholars like Girma and Shortland (2008), Gani and Ngassam (2008), Baida et al. (2009), Law and Habibullah (2009), Demetriades and Fielding (2009), Beji and Youssef (2010), all clearly highlighted the significance of institutions and institutional quality on finance and financial development which include factors as political stability, rule of law, government efficiency, and control of corruption. All of these researches followed similar advanced quantitative technics to come up with a similar conclusion where most of the theory of law and finance relies up on (La Porta et al., 1998). We can observe that all the theories developed states that the institutional quality and legal system has the ability to influence the efficiency and effectiveness of the financial system, financial development, and long-term economic growth and stability of an economy. Lack of 
institutional governance and functional legal systems can potentially lead to adverse effects that cause undesirable outcomes in the economy of a country both internally and externally.

Empirical evidences found that most of the emerging and developing countries experience lower degree of financial development and economic growth mainly due to lack of well-stablished legal system and a good quality institution which are fundamental foundations to promote and foster financial system progress and development. Many of the emerging and developing countries are characterized by having economic, political, financial, and regulatory frameworks that do not serve the basic need of the population. Vast number of population in those countries live below poverty line or have low standards of living due to slow economic and financial progress. Frequent political and social disruptions cause abnormal economic and financial volatilities limiting the progress and growth levels in those economies. International Monetary Fund (IMF) (2015) release on "Rethinking Financial Deepening: Sustainability and Growth in Emerging Markets" evidently found that financial system in emerging economies have deepened sustainably over the last decades, but most are well below the level reached by advanced economies. The study observed, however, that the pace of financial development matters to certain degrees. This is to say when deepening of financial institutions goes fast, it can potentially lead to financial and economic instabilities through encouraging high risk-taking actions and excessive leverages, which makes it very clear the premium of creating a good quality institution is vital in avoiding or minimizing those adverse effects of a positive outcome of financial deepening. This result is supportive to our expectation that well-designed institutional quality can promote a rather smoother financial and economic transition and development in emerging economies.

A recent article by Hayat Khan, Sher Khan, and Fan Zuojun (2020) on institutional quality and financial development of developing and emerging economies used a panel dataset of 189 countries to study the relationship between institutional quality and financial development in developing and emerging economies. Based on GMM experimental study, their research found that better institutions are important for financial development, specifically political stability, control of corruption, and regulatory quality positively affect financial development. The study further showed that due to its feeble nature, the rule of law negatively affects financial development in most emerging economies. On the contrary, however expectedly, control of corruption affects financial development positively and significantly suggesting that good quality institutions are main drivers of financial development progress and stability. Beck et al. (2003) examined the relationship between financial development and legal system of a country and the size of the largest private firms. The study employed a cross panel data analysis for a sample of 44 countries that include developing and developed economies from the period covering 1988-1997 and found that in countries with efficient legal system the large firms are larger. Most researches empirically proved that there is a linear correlation between financial development and institutional quality showing that countries with well-stated legal system and good quality institutions have the ability to grow and progress in more stable path than countries with weaker legal system and undeveloped institutional governance system. The LLSV series of papers $(1997,1998)$ examined the relationship between the legal determinants of financial sector and financial development and economic growth by assembling data pertaining the rights of investors and the quality of enforcing rules according to which their findings highly stressed the importance of governance and legal system in determining the growth of financial development. In a similar way, Pistor et al. (2000) has underscored that the legal system and institutional governance plays a vital role in promoting and fostering the equity and credit market development. The strong empirical evidence suggests that countries that advocate for functional legal system and effective governance tend to experience positive effects on their financial development and economic growth and stability. However, it is vital to mention that other variables also play significant role to shape the financial sector development and economic enhancement. Those variables include financial inclusion, trade openness, population, GDP, inflation, interest rate, exchange rates, money supply, resource allocation, and others play direct or indirect role in the growth and stability of financial development.

\section{Methodology and Data Description}

The dataset puts together 20 years of annual data between 1999 and 2019 for 26 emerging countries. It draws on a number of data sources: The World Bank FinStats (Feyen, Kibuuka, and Sourrouille, 2014), IMF's Financial Access Survey, World Governance Indicators, and Bank for International Settlement (BIS) debt securities database. ${ }^{1} \mathrm{~A}$ vast body of literature estimates the impact of financial development on economic growth, inequality, and stability. A typical empirical study proxy's financial development with either one of two measures of financial depth - the ratio of private credit to GDP or stock market capitalization to GDP.

Generalized Method of Moments (GMM) will be applied to help us analyze the moments of economic and financial progress by constructing regression models. The generalized method of moments (GMM) is a method for constructing estimators, analogous to maximum likelihood (ML). GMM uses assumptions about specific moments of the random variables instead of assumptions about the entire distribution which makes it more robust than ML at the cost of some efficiency. The assumptions are called moment conditions. GMM generalizes the

\footnotetext{
${ }^{1}$ Financial Development Index Database, International Monetary Fund (IMF) strategy, Policy, and Review Department.
} 
method of moment (MM) by allowing the number of moment conditions to be greater than the number of parameters. Using these extra moment conditions makes GMM more efficient that MM. when there are moment conditions than parameters, the estimator is said to be over-identified. GMM can efficiently combine the moment conditions when the estimator is over-identified. Potential endogeneity issues in the paradigm of institutional quality and financial development is usually unincorporated in many researches which can potentially lead a biased and unrealistic estimations and conclusion. However, using 2SLS least square method by involving an IV approach can help to overcome the problem of endogeneity.

$F D_{i t}=a F D_{i t-1}+a_{1} P S_{i t}+a_{2} R Q_{i t}+a_{3} R L_{i t}+a_{4} C C_{i t}+a_{5} G E_{i t}+a_{6} V A_{i t}+a_{7} T O_{i t}+a_{9} \log P O P_{i t}+a_{8} G S_{i t}+$

$a_{10} C A P F O R_{i t}+\varepsilon_{i t}$

\section{Empirical Analysis}

FD is the financial development for private sector credit bank, proxies for financial development as a share of GDP, PS is the political stability, RQ represents the regulatory quality, RL is the rule of law, COC shows the control of corruption, GE is used to indicate the government effectiveness, VA represents the voice and accountability, POP is the population, GS is the saving, Cap-For is the capital formation used for private investment, while TO represents the trade openness which distress financial development, explained by Svaleryd and Vlachos (2002) and also by Rajan and Zingales (2003), Chinn and Ito (2006), Braun and Raddatz (2008), Law and Azman-Saini (2008) as well by Baltagi, Demetriades, and Law (2009). According to Levine and Zervos (1996), when the market size increases, its ability also increases to generate more funds and diversify risk incensement. Credit to private sector shows that the financial funds which is provided to the private sector through loan purchases and of no equity securities, the trade credits and also the accounts receivable that launch a rights for the repayment. While for some countries, these comprise the credit to public enterprises. The countries selected in the sample are all from the emerging economies categories. The baseline estimations of IQ and its subcomponents are presented in table 2. The findings indicate the magnitude of influence of the subcomponents of IQ on financial development (FD).

Table 1. Descriptive Statistics

\begin{tabular}{|c|c|c|c|c|c|c|}
\hline \multicolumn{2}{|c|}{ Variable } & \multirow[t]{2}{*}{ Observations } & Mean & Std. Dev & Min & \multirow{2}{*}{$\begin{array}{l}\text { Max } \\
3.764\end{array}$} \\
\hline$\overline{\mathrm{FD}}$ & 457 & & $4.70 \mathrm{e}-09$ & 1.000 & -1.346 & \\
\hline IQ & 457 & & $3.50 \mathrm{e}-09$ & 1.000 & -2.346 & 3.764 \\
\hline PS & 457 & & 1.948 & 4.345 & -0.975 & 20.412 \\
\hline RQ & 457 & & 2.283 & 1.808 & -2.757 & 9.713 \\
\hline RL & 457 & & 11.320 & 1.248 & 8.437 & 14.717 \\
\hline $\mathrm{CC}$ & 457 & & 5.940 & 0.911 & 2.96 & 7.58 \\
\hline GE & 457 & & 18.213 & 0.832 & 2.56 & 36.510 \\
\hline VA & 457 & & 0.428 & 0.243 & 0.045 & 0.850 \\
\hline TO & 457 & & 6.264 & 11.686 & -32.752 & 91.758 \\
\hline GS & 457 & & 111.269 & 16.637 & 78.4 & 175.9 \\
\hline CAPFC & R457 & & 117.486 & 59.165 & 3.343 & 316.4 \\
\hline $\log \mathrm{PO}$ & 457 & & $2.54 \mathrm{e}-09$ & 1.000 & 2.356 & 1.804 \\
\hline RETF & 457 & & 0.538 & 0.342 & 0.032 & 0.750 \\
\hline
\end{tabular}

We have used Religious and Ethnic Fragmentation (RETF) as an instrumental variable of Institutional Quality (IQ) which was proposed by ICRG that can affect institutions in the society in higher magnitude which in turn this issue will have an impact on financial development. To show the interaction between the instrumental variable RETF and IQ, we first estimated the first and second order differences. Table 4 plots the results of the instrumented variable and IQ for first and second stage 2SLS estimations.

In order to obtain a reliable result, we have used OSL, fixed effects (FE), DGMM, random effects regression, and system-GMM models for the sample data of 26 emerging countries. However, the main focus is in using the system-GMM. The other models are basically applied to have a batter picture in comparison and robustness results. The consistency of the GMM estimator mainly depends on the assumptions that the error terms do not exhibit second order serial correlation and that the instruments are valid. To check whether or not these assumptions hold, we conducted Sargan test for over-identification and serial correlation tests. Failure to reject the null hypothesis of these tests implies that the assumptions of the estimation hold. We also run Wald (joint-significance) test. As it is presented in table 5.4, from the diagnostic statistics, we see the tests do not reject the econometric specification of the model. In all the GMM specifications, the test for first-order serial correlation rejects the null of no firstorder serial correlation but does not reject the null of no second-order serial correlation. 
Table 2. OSL baseline model estimation of IQ and its sub-components

\begin{tabular}{|c|c|c|c|c|c|c|c|}
\hline \multirow[b]{2}{*}{ Variable } & \multicolumn{7}{|c|}{ Dependent Variable: $F D$} \\
\hline & (1) & (2) & (3) & (4) & (5) & (6) & (7) \\
\hline$\overline{\mathrm{IQ}}$ & $\begin{array}{l}0.312^{* * *} \\
(5.41)\end{array}$ & & & & & & \\
\hline$P S$ & & $\begin{array}{l}1.436^{* * * *} \\
(5.47)\end{array}$ & & & & & \\
\hline$R Q$ & & & $\begin{array}{l}3.775^{* * *} \\
(6.74)\end{array}$ & & & & \\
\hline$R L$ & & & & $\begin{array}{l}2.107^{*} \\
(6.58)\end{array}$ & & & \\
\hline $\begin{array}{l}-0 . \\
(-1\end{array}$ & $\begin{array}{l}702 * * \\
.55)\end{array}$ & & & & & & \\
\hline$G E$ & & & & & & $\begin{array}{l}1.965^{*} \\
(5.41)\end{array}$ & \\
\hline$V A$ & & & & & & & $\begin{array}{l}0.326^{* *} \\
(0.79)\end{array}$ \\
\hline TO & $\begin{array}{l}0.265^{* *} \\
(4.06)\end{array}$ & $\begin{array}{l}0.410^{* * *} \\
(7.44)\end{array}$ & $\begin{array}{l}0.336^{* * *} \\
(6.03)\end{array}$ & $\begin{array}{l}0.345^{* * *} \\
(5.86)\end{array}$ & $\begin{array}{l}0.372 * * * \\
(6.06)\end{array}$ & $\begin{array}{l}0.265^{* *} \\
(4.06)\end{array}$ & $\begin{array}{l}0.350 * * * \\
(5.84)\end{array}$ \\
\hline$G S$ & $\begin{array}{l}0.248^{*} \\
(2.91)\end{array}$ & $\begin{array}{l}0.245^{* *} \\
(3.01)\end{array}$ & $\begin{array}{r}0.046 \\
(0.51)\end{array}$ & $\begin{array}{l}-0.204 * * \\
(-2.01)\end{array}$ & $\begin{array}{l}0.169^{*} \\
(1.91)\end{array}$ & $\begin{array}{c}0.248^{* * * *} \\
(2.91)\end{array}$ & $\begin{array}{c}0.093 \\
(1.11)\end{array}$ \\
\hline $\log P O P$ & $\begin{array}{l}-0.003 * \\
(-1.70)\end{array}$ & $\begin{array}{l}-0.004 * * \\
(-2.02)\end{array}$ & $\begin{array}{l}-0.001 \\
(-0.59)\end{array}$ & $\begin{array}{l}-0.001 \\
(-0.50)\end{array}$ & $\begin{array}{l}-0.002 \\
(-1.01)\end{array}$ & $\begin{array}{l}-0.003^{*} \\
(-1.70)\end{array}$ & $\begin{array}{l}-0.002 \\
(-1.11)\end{array}$ \\
\hline CAPFOR & $\begin{array}{r}0.005 \\
(1.32)\end{array}$ & $\begin{array}{l}-0.004 \\
(-1.38)\end{array}$ & $\begin{array}{l}-0.014 * * * \\
(-5.82)\end{array}$ & $\begin{array}{l}-0.010^{* * *} \\
(-3.23)\end{array}$ & $\begin{array}{l}-0.012 * \\
(-4.11)\end{array}$ & $\begin{array}{r}0.005 \\
(1.32)\end{array}$ & $\begin{array}{c}-0.012 * * * \\
(-3.89)\end{array}$ \\
\hline Constant & $\begin{array}{l}-5.014 * * * \\
(-5.09)\end{array}$ & $\begin{array}{c}-6.006^{* * *} \\
(-5.76)\end{array}$ & $\begin{array}{l}-6.398 * * * \\
(-5.96)\end{array}$ & $\begin{array}{c}-5.091 * * * \\
(-4.79)\end{array}$ & $\begin{array}{c}-6.309 * * * \\
(-7.48)\end{array}$ & $\begin{array}{c}-6.082 * * * \\
(-6.38)\end{array}$ & $\begin{array}{c}-5.742 * * * \\
(-5.27)\end{array}$ \\
\hline Fixed Effects & Yes & Yes & Yes & Yes & Yes & Yes & Yes \\
\hline Observations & 457 & 457 & 457 & 457 & 457 & 457 & 457 \\
\hline $\begin{array}{ll}\text { Adj. } & \text { R- } \\
\text { squared }\end{array}$ & 0.567 & 0.675 & 0.308 & 0.424 & 0.422 & 0.675 & 0.421 \\
\hline
\end{tabular}

Thus, we conclude that the GMM estimators are valid and consistent because the Sargan test supports the validity of the instruments and from the second-order serial correlation test we cannot reject the hypothesis of the absence of second-order serial correlation. According to Baltagi et al. (2008) if lagged dependent variable is included in the model, all estimated beta coefficients represent short run effects. The long run effect can be derived by dividing each of the betas by 1 minus the coefficient of the lagged dependent variable.

The above findings are self-indicative that good quality institutions and good governance promotes and fosters the financial development and economic growth. It is also evident from the results that the quality of institutions and institutional quality has the power to strengthen the correlation between financial development and economic growth by creating a better financial environment and enhancing financial development. The results also are parallel with our initial hypothesis proving that there exists strong relationship between institutions and financial development and answers the question if institutional quality has a role in fostering financial development in emerging economies. 
Table 3. IQ instrumented with RETF

\begin{tabular}{|c|c|c|}
\hline \multicolumn{3}{|c|}{ Dependent Variable: $F D$} \\
\hline \multirow[b]{3}{*}{ Variable } & First Stage & Second stage \\
\hline & $I Q$ & $F D$ \\
\hline & (1) & (2) \\
\hline Instrument & $\begin{array}{l}-0.432 * * * \\
(-2.56)\end{array}$ & \\
\hline IQ (Instrumented) & & $\begin{array}{l}1.875^{* *} \\
(1.76)\end{array}$ \\
\hline TO & $\begin{array}{l}0.214^{* * *} \\
(5.12)\end{array}$ & $\begin{array}{l}-0.079 \\
(-0.40)\end{array}$ \\
\hline$G S$ & $\begin{array}{l}-0.441^{* * * *} \\
(-3.92)\end{array}$ & $\begin{array}{l}0.867 * * \\
(2.47)\end{array}$ \\
\hline $\log P O P$ & $\begin{array}{l}-0.012 \\
(-1.18)\end{array}$ & $\begin{array}{r}0.015 \\
(0.73)\end{array}$ \\
\hline CAPFOR & $\begin{array}{l}-0.048^{* * *} \\
(-1.27)\end{array}$ & $\begin{array}{l}0.091 * * \\
(3.41)\end{array}$ \\
\hline Constant & $\begin{array}{l}0.276 \\
(0.40)\end{array}$ & $\begin{array}{l}-4.654 * * * \\
(-3.39)\end{array}$ \\
\hline Fixed Effects & Yes & Yes \\
\hline Observations & 457 & 457 \\
\hline Adj. R-squared & 0.423 & NA \\
\hline
\end{tabular}

The results estimated using 2SLS model by instrumenting IQ using RETF showed a slight variation in pattern with the OLS model estimation. Table 5. shows the estimation results of instrumented IQ and the control variables and their degree of statistical significance. Unlike the results from OSL estimations, all the variables and control variables proved to be strongly and significantly relevant to explain financial development. Voice and accountability continued to influence financial development conversely. All other variables were able to positively impact financial development. All the variables of institutional quality except for rule of law and voice and accountability, proved to be statistically significant to explain financial development in all the sample emerging countries used in the study. The results are robust and similar to the findings shown used OLS and SGMM models in previous tables. The positive coefficients of PS, RQ, CC, and GE indicates that sound and functional institutions with no or low levels of religious and ethnic fragmentations. This in turn explains the strong social bound with less or no fragmentations help to create strong institutions that would highly contribute to the financial development. According to ICRG, the components of IQ are rated in a100 point basis indicating that highest points shows less risk of religious and ethnic fragmentation which in turn explains high institutional quality. The reverse is true for scoring less points indicating high risk of religious and ethnic fragmentation which explains less institutional quality. When there is high institutional quality, financial development progresses faster and regresses faster under less institutional quality environment. (La Porta et al. 1999, Alesina et al. 2003).

The above findings show the solid relationship between institutional quality and financial development. We have noticed that financial development tends to respond positively to any positive changes and improvements in the quality of institutions. Such response of financial development to improvements in institutional quality helps to draw a line that there is high magnitude and role of institutional quality to promote and foster financial development in emerging countries. All components of institutional quality affects financial development significantly. However, it should be noted that there is still ambiguity on how voice and accountability affects financial development. The variable however significant tends to have a converse impact on financial development. This indicates that further and deeper research is required to find out on how voice and accountability (defined as: perceptions of the extent to which a country's citizens can participate in selecting their government, as well as freedom of expression, freedom of association, and free media) can affect financial development and if so, what are the potential degree of impact. Besides, the variable rule of law (RL) tends to affect financial development somehow negatively by exerting more bureaucratic pressure on economic and financial practices. High degree of rule of law is potential of creating undesirable economic and financial environment by making complicated policies and inconvenient bureaucracies. Therefore, finding an equilibrium of optimal amount of the impact of rule of law over financial development is crucial to minimize the converse pressure.

\section{Conclusion}

The performance of financial development mainly depends on the quality of institutions, regulatory framework, and good governance. The governance system of the pillars and sectoral institutions of an economy determines the 
effectiveness of the impact that these institutions have on the growth and progress of financial development. The concept of institutional quality has been gaining enormous attention lately unlike the other times. This is due to the necessity of institutions in have strong foundations in the society, politics, economies, finance, investments, and other aspects of the countries. The domestic and international aspects of the economy, trade, and finance does not function effectively unless there are efficient and well-performing institutions. Emerging countries have been the focus and source of significant world economic progress in recent year. This includes investments, trade, production, source of finance, manufacturing, and human resources. To attain the objectives of the expected and required financial and economic targets, emerging economies need to strengthen the qualities of their institutions, regulatory frameworks, and their governance aspects.

The relationship between the quality of institutions and financial development is unparalleled that emerging markets need to address the issues of the different components such as political stability, regulatory quality, rule of law, control over corruption, government effectiveness, and voice and accountability. These components have shown strong influence over financial development in many aspects. However, it is worth mentioning that all these factors collectively or separately function differently in different emerging countries depending on their internal conditions. Some emerging economies including China, South Africa, Brazil, Russia, and Indonesia have been making great progress in their institutional qualities which have helped them to attain high rates of financial development in shorter period of time compared to other emerging economies. The other emerging countries are expected to follow similar steps to enhance and foster their financial development by increasing their institutional qualities.

\section{References}

North D. (1990) Institutions, Institutional Change and Economic Performance. Political Economy of Institutions and Decisions, pp. 1-10, 71-94). Cambridge University Press.

Andrianova, S., Demetriades, P., \& Shortland, A. (2008). Government ownership of banks, institutions, and financial development. Journal of Development Economics, 85(1-2), 218-252.

Anwar, S., \& Cooray, A. (2012). Financial development, political rights, civil liberties and economic growth: Evidence from South Asia. Economic Modelling, 29(3), 974-981.

Arcand, J. L., Berkes, E., \& Panizza, U. (2015). Too much finance? Journal of Economic Growth, 20(2), $105-148$.

Arellano, M., \& Bond, S. (1991). Some tests of specification for panel data: Monte Carlo evidence and an application to employment equations. The Review of Economic Studies, 58(2), 277-297.

Arellano, M., \& Bover, O. (1995). Another look at the instrumental variable estimation of error-components models.Journal of Econometrics, 68(1), 29-51.

Asiama, J., \& Mobolaji, H. (2011). Trade and financial openness, institutional quality, and financial development in sub-Sahara Africa (SSA). Paper presented at the International conference on international trade and investment (ICITI).

Baltagi, B. H., Demetriades, P. O., \& Law, S. H. (2009). Financial development and openness: Evidence from panel data. Journal of Development Economics, 89(2), 285-296.

Baltagi, B. H., Egger, P., \& Pfaffermayr, M. (2007). Estimating models of complex FDI: Are there third-country effects? Journal of Econometrics, 140(1), 260-281.

Beck, T., Clarke, G., Groff, A., Keefer, P., \& Walsh, P. (2001). New tools in comparative political economy: The database of political institutions. The World Bank Economic Review, 15(1), 165-176.

Jeremy Greenwood and Bruce D. Smith, "Financial markets in development, and the development of financial markets" Journal of Economic Dynamics and Control 21 (1997)145-181.

Levine Ross, Zervos Sara, “Stock Markets, Banks, and Economic Growth” Journal of American Economic Review volume 88, 1998/02/01

Levine Ross, "Bank-Based or Market-Based Financial System: Which one is better?" Journal of Financial Intermediation, vol. 11, issue 4, 398-428, 2002

Valerie R. Bencivenga; Bruce D. Smith, "Financial Intermediation and Endogenous Growth" The Review of Economic Studies, Vol. 58, No. 2. (Apr., 1991), pp. 195-209

Raghuram G. Rajan \& Luigi Zingales, "Financial Dependence and Growth” Economic Review, Vol. 88, no. 3 (1998): 559-586, Sept 1, 1996

Jeremy Greenwood, Bruce D. Smith, "Financial markets in development, and the development of financial markets" Journal of Economic Dynamics and Control 21 (1997) 145-181

Afangideh, U. J., Garbobiya, T. S., Umar, F. B., \& Usman, N. (2020). “The impact of inflation on financial sector development: Evidence from Nigeria” International Journal of Economics and Finance, 12(2), 1-56

Bencivenga, Valerie R. and Bruce D. Smith, 1991, "Financial intermediation and endogenous growth", Review of Economic Studies 58, 195-209.

$\mathrm{Hsu}$, Tian and $\mathrm{Zu}$, "Financial Developemtn and Innovation: Cross-Country Evidence" Journal of Financial Economics vol. 112, issue 1, 116-135, 2014 
Baltagi, B. H., Demetriades, P. O., \& Law, S. H. (2009). Financial development and openness: Evidence from panel data. Journal of Development Economics, 89(2), 285-296

E. Han Kim and Vijay Singal, "Stock Market Openings: Experience of Emerging Economies" The Journal of Business, Vol. 73, No. 1 (January 2000), pp. 25-66

Rousseau, P.L., and P. Wachtel (2000), "Equity Markets and Growth: Cross-country Evidence on Timing and Outcomes, 1980-1995," Journal of Banking and Finance, 24, 1933-1957.

Guglielmo Maria Caporale \& Peter G. A Howells \& Alaa M. Soliman, "Stock Market Development and Economic Growth: The Causal Linkage," Journal of Economic Development, Chung-Ang Unviersity, Department of Economics, vol. 29(1), pages 33-50, June 2004

Huang, Ho-Chuan and Chih-Chuan Yeh, "Level, structure, and volatility of financial development and inflation targeting", Journal of Empirical Finance, 44, (C), 108-124, 2017

Valpy Fitz Gerald, "Finance and Growth in Developing Countries: Sound Principles and Unreliable Evidence" QEH Working Papers, Queen Elizabeth House, University of Oxford

Castaneda, Gonzalo, "Economic growth and concentrated ownership in stock markets," Journal of Economic Behavior and Organization, Elsevier, vol. 59(2) pages 249-286, February 2006

Ratna Sahay, Martin Čihák, Papa N'Diaye, Adolfo Barajas, Ran Bi, Diana Ayala, Yuan Gao, Annette Kyobe, Lam Nguyen, Christian Saborowski, Katsiaryna Svirydzenka, and Seyed Reza Yousefi, "Rethinking Financial Deepening: Stability and Growth in Emerging Markets" IMF Staff Discussion Note SDN/15/08, May 2015.

Katsiaryna Svirydzenka, "Introducing a New Broad-based Index of Financial Development" IMF Working Paper WP/16/5, January 2016

Charles Amo Yartey and Charles Komla Adjasi Stock Market Development in Sub-Saharan Africa: Critical Issues and Challenges. IMF working paper WP/07/209

Alonso-Borrego, C., and M. Arellano (1999), "Symmetrically Normalized Instrumental Variable Estimation Using Panel Data," Journal of Business and Economic Statistics, 17, 36-49.

Arellano, M., and S. Bond (1991), "Some Tests of Specification for Panel Data: Monte Carlo Evidence and an Application to Employment Equations,” Review of Economic Studies, 58, 277-297.

Arellano, M., and O. Bover (1995), “Another Look at the Instrumental-Variable Estimation of Error-Components Models," Journal of Econometrics, 68, 29-52.

Atje, R., and B. Jovanovic (1993), “Stock Markets and Development,” European Economic Review, Vol. 37, 632640.

Beck, T., and R. Levine (2003), “Stock Markets, Banks, and Growth: Panel Evidence,” Journal of Banking and Finance, forthcoming.

Beck, T., R. Levine, and N. Loayza (2000), "Finance and the Sources of Growth," Journal of Financial Economics, 58, 261-300.

Bekaert, G., C.R. Harvey, and C. Lundblad (2003), “Does Financial Liberalization Spur Growth?” Working Paper, Fuqua School of Business, Duke University, Durham, NC, USA.

Bernanke and Gertler (1990), "Financial Fragility and Economic Performance," Quarterly Journal of Economics, Vol. 55, 87-114.

Calderon, C., A. Chong, and N. Loayza (2000), "Determinants of Currenr Account Deficits in Developing Countries,” World Bank Research Policy Working Paper 2398.

Caporale, G.M., and N. Pittis (1997), “Causality and Forecasting in Incomplete Systems,” Journal of Forecasting, Vol. 16, 425-437

Cho, Y.J. (1986), "Inefficiencies from Financial Liberalization in the Absence of Well-Functioning Equity Markets," Journal of Money, Credit, and Banking, Vol. 18, 191-199.

Dailami, M., and M. Atkin (1990), "Stock Markets in Developing Countries: Key Issues and A Research Agenda," Policy Research and External Affairs Working Papers, The World Bank.

Demetriades, P., and K. Hussein (1996), "Does Financial Development Cause Economic Growth: Time-Series Evidence from 16 Countries," Journal of Development Economics, Vol. 51, 387-411.

Demirguc-Kunt, A. (1994), "Developing Country Capital Structure and Emerging Stock Markets," Policy Research Working Paper, WPS 933, July.

Demirguc-Kunt, A., and R. Levine (1995), "Stock Markets, Corporate Finance, and Economic Growth: An Overview," Working Paper, World Bank, No 1389.

EMDB (1998), “Emerging Markets Data Base,” International Finance Corporation (IFC), Washington D.C. 